\title{
Association between Duration of Protease Inhibitor Therapy and BMI in HIV Patients
}

\author{
Muhammad Arif Habibi Nasution*, Aron Pase ${ }^{1}$, Melati Silvanni Nasution", \\ Santi Syafril ${ }^{1}$, Dharma Lindarto ${ }^{1}$
}

\author{
*Department of Internal Medicine, Faculty of Medicine, Universitas Sumatera Utara \\ ${ }^{1}$ Division of Endocrinology Metabolic and Diabetes, Department of Internal Medicine, Faculty of Medicine, \\ Universitas Sumatera Utara
}

Corresponding Author: Muhammad Arif Habibi Nasution

\begin{abstract}
Introduction: The prognosis of HIV had changed dramatically from a deadly infectious disease into a manageable infection. Initiation of $\mathrm{ARV}$, especially protease inhibitor, was thought to be associated with metabolic abnormalities. Weight gain in HIV could be a positive indicator for better prognosis. However, excessive weight gain was associated with deleterious effects. Studies regarding protease inhibitor in weight gain had different results. In this study, we intend to identify association of PI therapy duration with BMI.

Methods: We conducted a cross-sectional study in Adam Malik Hospital, Medan from August to December 2019. We recruited HIV patients above 18 years old during the outpatient with at least 6-month duration of PI therapy. During visits, patients were screened for inclusion criteria and assessed for BMI. Fasting blood glucose and insulin plasma sample were taken in the morning. Data was analysed by SPSS 22.0.

Results: Thirty-five subjects fulfilled inclusion criteria, 25 of subjects were males $(71.4 \%)$. Mean age of subjects was $38.85 \pm 9.7$ years. Data analysis presented that there were no significant differences between two groups of treatment $\left(24.33 \pm 3.3 \mathrm{~kg} / \mathrm{m}^{2}\right.$ vs $24.39 \pm 5.0$ $\mathrm{kg} / \mathrm{m}^{2} ; p=0.966$ ). There were significant differences between two groups regarding fasting blood glucose level $(84.4 \pm 6.8 \mathrm{mg} / \mathrm{dL}$ vs $114.9 \pm 53.6 \mathrm{mg} / \mathrm{dL} ; p=0.015)$ and fasting insulin level $(7.28 \pm 3.4 \mu \mathrm{U} / \mathrm{mL}$ vs $26.01 \pm 23.5$ $\mu \mathrm{U} / \mathrm{mL} ; p=0.000)$.
\end{abstract}

Conclusion: BMI was not associated with duration of PI therapy in our study. Fasting blood glucose and fasting insulin were significantly higher between groups.

Keywords: HIV, protease inhibitor, BMI, insulin, obesity, weight gain

\section{INTRODUCTION}

HIV has remained as global burden worldwide for almost five decades. ${ }^{[1,2]}$ It was estimated that 38 million people living with HIV the end of 2019. ${ }^{[3,4]}$ While global treatment and efforts for HIV have advanced, the number of people living with HIV (PLWH) keeps raising when receiving antiretroviral therapy. According to Joint United Nations Programme on HIV and AIDS data, $67 \%$ of adults and 53\% of children living with HIV globally were receiving lifelong antiretroviral therapy (ARV) in 2019. ${ }^{4]}$ The prognosis of HIV had changed dramatically from a deadly infectious disease into a manageable infection. ${ }^{[5]}$

As the life expectancy of HIV are increasing, non-infectious comorbidity has affected PLWH. ${ }^{[6]}$ Overweight and obesity has reached high number in PLWH during the last 2 decades in United States. ${ }^{[7]}$ In previous study, a HIV clinic was reported to have a high proportion with the prevalence of multiple comorbidities which was associated with increased BMI (body mass index). ${ }^{[8]}$ Even though weight gain in HIV could be a positive indicator for better prognosis, [9] excessive weight gain was 
associated with deleterious effects in cardiovascular and metabolic parameters ${ }^{[10]}$

Instead of achieving virological control and increased global aging of PLWH population, initiation of ARV is thought to be associated with some metabolic abnormalities, such as, dyslipidemia, insulin resistance, and weight gain. ${ }^{[1,7,11]}$ Previous in vitro study showed that protease inhibitors inhibited the activity of GLUT-4 (glucose transporter-4) and lipodystrophy in PLWH. ${ }^{[12]}$ Other studies have also established the associations between PI and wide range of its adverse effects. [1,13] However, the clinical significance of these findings is still yet to be known. ${ }^{[14,15]}$

To our knowledge, studies regarding ARV therapy in weight gain had different results. ${ }^{[11,16,17]}$ PI therapy was associated with weight gain in some studies. $[1,11,18]$ Todd et al reported PI drugs were not associated with overweight or obesity. ${ }^{[19]}$ Another study by Obry-Roguet et al was also failed to find this association. ${ }^{[20]}$ Apart from weight gain, Noor et al reported that $\mathrm{LPV} / \mathrm{r}$ (lopinavir/ritonavir) was found to induce insulin resistance in 5 days period. ${ }^{[21]}$ Study by Dirajral-Fargo et al also found that atazanavir-ritonavir (ATV/r) and darunavir-ritonavir (DRV/r) were associated with insulin resistance in 4-week ARV therapy. [22] Taking into account the variabilities of available studies, we intend to identify PI therapy duration and its association with BMI.

\section{METHODS}

This cross-sectional study was performed in Adam Malik Hospital, Medan from August 2019 to December 2019. The study was reviewed and approved by Health and Research Ethics Committee of Medical Faculty University of Sumatera Utara. We enrolled HIV patients above 18 years old in outpatient clinic with at least 6-month duration of PI therapy as current treatment. Individuals with abnormal kidney function tests, history of diabetes, and taking other drugs affecting the insulin resistance and blood glucose were excluded.

During the outpatient visits, patients were interviewed for medical history and current medications. After being screened for the inclusion criteria, informed consent was obtained for all subjects. Subjects were assessed for BMI and blood pressure. In all subjects, fasting blood glucose and insulin plasma sample were taken in the morning. Insulin plasma was measured using chemiluminescent (sandwich) immunoassay from serum/plasma added with lithium heparin or K3 EDTA or sodium citrate. BMI was classified according to Asia Pacific Classification. ${ }^{\text {[23] }}$

Data was analysed by software SPSS 22.0. Shapiro-wilk test was used to confirm normal distribution of data. For assessing comparison between duration of PI treatment and BMI, we used t-test if data was normally distributed. Mann-Whitney U test was used if data had non-normal distribution. $P$ value $<0.05$ was considered significant. If data was normally distributed, data were shown as mean \pm standard deviation (SD).

\section{RESULT}

\section{Demographic of Subjects}

Thirty-five subjects fulfilled inclusion criteria (Table 1). There were 25 males $(71.4 \%)$ and 10 females (28.6\%). Mean age of subjects was $38.85 \pm 9.7$ years, with the oldest was 64 years old and the youngest was 18 years old. Mean systolic blood pressure was $110.57 \pm 10.2 \mathrm{mmHg}$ and diastolic blood pressure was $74.57 \pm 7.4$ $\mathrm{mmHg}$. All of the subjects had normal blood pressure.

Table 1. Characteristics of Subjects

\begin{tabular}{|l|l|}
\hline Subject Characteristic & Mean \\
\hline Age (years) & $38.85 \pm 9.7$ \\
\hline Male $(\%)$ & $25(71.4 \%)$ \\
\hline Body Mass Index $\left(\mathrm{kg} / \mathrm{m}^{2}\right)$ & $24.35 \pm 3.9$ \\
\hline Systolic Blood Pressure $(\mathrm{mmHg})$ & $110.57 \pm 10.2$ \\
\hline Diastolic Blood Pressure $(\mathrm{mmHg})$ & $74.57 \pm 7.4$ \\
\hline Fasting Blood Glucose $(\mathrm{mg} / \mathrm{dL})$ & $96.6 \pm 36.8$ \\
\hline Fasting Insulin $(\mu \mathrm{U} / \mathrm{mL})$ & $14.77 \pm 17.4$ \\
\hline Duration of treatment & \\
\hline $6-12$ months $(\%)$ & $15(44.1 \%)$ \\
\hline$>12$ months $(\%)$ & $19(55.9 \%)$ \\
\hline
\end{tabular}



HIV patients.

Duration of treatment using PI-type of ARV drugs in this study was divided into two groups, which was six to 12 months and more than 12 months. Nineteen subjects had already been on the treatment of more than 12 months.

\section{Comparison of Body Mass Index and The Duration of Treatment}

Mean BMI of subjects were $24.35 \pm$ $3.9 \mathrm{~kg} / \mathrm{m}^{2}$, with the highest BMI was 33.06 $\mathrm{kg} / \mathrm{m}^{2}$ and the lowest BMI was $14.72 \mathrm{~kg} / \mathrm{m}^{2}$. Most of the subjects had normal weight $(13.27 \%)$ (Table 2). There was one $(2.9 \%)$ underweight subject, seven (20\%) overweight subjects, $11(31.4 \%)$ obese I subjects, and three $(4.6 \%)$ obese II subjects.

Table 2. Distribution of Body Mass Index of Subject

\begin{tabular}{|l|l|l|}
\hline Body Mass Index & $\mathbf{n}$ & \% \\
\hline Underweight & 1 & $2.9 \%$ \\
\hline Normal & 13 & $37.1 \%$ \\
\hline Overweight & 7 & $20 \%$ \\
\hline Obese I & 11 & $31.4 \%$ \\
\hline Obese II & 3 & $4.6 \%$ \\
\hline
\end{tabular}

Distribution of BMI data was analyzed using Shapiro-Wilk and had normal distribution $(p=0.424)$. Comparison of BMI and duration of treatment showed no significant difference between two groups $\left(24.33 \pm 3.3 \mathrm{~kg} / \mathrm{m}^{2}\right.$ vs $24.39 \pm 5.0$ $\left.\mathrm{kg} / \mathrm{m}^{2} ; p=0.966\right)$ (Table 3$)$.

Table 3. Comparison of Body Mass Index, Fasting Blood Glucose, Fasting Insulin Level and Duration of Treatment

\begin{tabular}{|l|l|l|l|}
\hline Variables & 6-12 months & $>12$ months & p \\
\hline $\begin{array}{l}\text { Body Mass Index } \\
\left(\mathrm{kg} / \mathrm{m}^{2}\right)^{*}\end{array}$ & $24.33 \pm 3.3$ & $24.39 \pm 5.0$ & 0.966 \\
\hline $\begin{array}{l}\text { Fasting Blood Glucose } \\
(\mathrm{mg} / \mathrm{dL}) * *\end{array}$ & $84.4 \pm 6.8$ & $114.9 \pm 53.6$ & 0.015 \\
\hline $\begin{array}{l}\text { Fasting Insulin } \\
(\mu \mathrm{U} / \mathrm{mL}) * *\end{array}$ & $7.28 \pm 3.4$ & $26.01 \pm 23.5$ & 0.000 \\
\hline *Unpaired-t-test; **Mann-Whitney U test & & \\
\hline
\end{tabular}

\section{Comparison of Fasting Blood Glucose and Fasting Insulin Level with Duration of Treatment}

Mean fasting blood glucose of subjects was $96.6 \pm 36.8 \mathrm{mg} / \mathrm{dL}$. Distribution of fasting blood glucose data was analyzed using Shapiro-Wilk and has non-normal distribution $(p=0.000)$. The analysis showed significant difference between two groups of treatment $(84.4 \pm 6.8$ $\mathrm{mg} / \mathrm{dL}$ vs $114.9 \pm 53.6 \mathrm{mg} / \mathrm{dL} ; p=0.015)$ (Table 3).

Mean fasting insulin level was 14.77 $\pm 17.4 \mu \mathrm{U} / \mathrm{mL}$. Distribution of fasting insulin data was analyzed using ShapiroWilk and has non-normal distribution ( $p=$ 0.000). Compative analysis of fasting insulin level and duration of treatment presented significant difference between two groups of treatment $(7.28 \pm 3.4 \mu \mathrm{U} / \mathrm{mL}$ vs $26.01 \pm 23.5 \mu \mathrm{U} / \mathrm{mL} ; p=0.000$ ) (Table $3)$.

\section{DISCUSSION}

The most age range of subjects were 34-49 years old. Most of the subjects were men, which contribute to $71.4 \%$ of subjects. Based on the study on 18,669 subjects, most of HIV patients are men with mean age of 47.5 years. ${ }^{[24]}$ Other study by Fiseha et al showed that mean age in their study were 37 years old. ${ }^{[25]}$ This result is similar to our studies, as it shows most patients tend to be infected in their teen or early adult years. Saktina et al stated that most people infected in 12 to 35 years old which may be caused by the productive groups tend to do high risk sexual activities these days. These activities included multiple sexual partners and negligence use of condoms. They also are more likely to use and share intravenous drugs. ${ }^{[26]}$

All subjects had normal blood pressure with mean systolic blood pressure $110.57 \pm 10.2 \mathrm{mmHg}$ and mean diastolic blood pressure $74.57 \pm 7.4 \mathrm{mmHg}$. In terms of hypertension, men are more likely to have it than women. The prevalence of hypertension was higher in older patients that in their younger counterparts. Other factors associated with hypertension in HIV patients are longer duration of HIV infection, family history of hypertension, high BMI, low CD4 count, DM comorbidity, and impaired renal function. ${ }^{[25]}$ HIV infected adults on ARV have higher prevalence of hypertension when compared with HIV-uninfected individuals. Several virological and treatment-related factors have been implicated in pathophysiology of 
hypertension in HIV infection, such as chronic inflammation, immune reconstitution and lipodystrophy. All of these will activate renin-angiotensinaldosterone system (RAAS). ${ }^{[27]}$ Study by Fiseha et al found that duration of ARV was associated with hypertension. ${ }^{[25]}$ However, the findings were different with study by Hatleberg et al stated. In their study, they failed to find evidence for any association between any ARV drugs and the risk of hypertension. ${ }^{[28]}$ Our results were aligned with Hatleberg et al that we did not find high blood pressure subjects. In this case, few considerations should be considered, as we only measure blood pressure at one occurrence and look up to previous medical record. Blood pressure were not repeatedly measured as recommended by Indonesian Society of Hypertension Guideline, ${ }^{[29]}$ no confounding comorbidity, such as DM that would contribute to hypertension. Further investigations regarding this matter are still needed.

Mean BMI of subjects were $24.35 \pm$ $3.9 \mathrm{~kg} / \mathrm{m}^{2}$, with the highest BMI was 33.06 $\mathrm{kg} / \mathrm{m}^{2}$ and the lowest BMI was $14.72 \mathrm{~kg} / \mathrm{m}^{2}$. Study by Araujo et al also stated mean BMI on HIV-patient with ARV were $23.9 \mathrm{~kg} / \mathrm{m}^{2}$. ${ }^{[30]}$ We found that there was no significant difference of BMI between two groups of treatment $\left(24.33 \pm 3.3 \mathrm{~kg} / \mathrm{m}^{2}\right.$ vs $24.39 \pm 5.0$ $\left.\mathrm{kg} / \mathrm{m}^{2} ; p=0.966\right)$. This result was aligned with study by Tshikuka et al. Tshikuka et al conducted a 12-year cohort study to assess ARV regimens that predicts overweight, obesity, and other factors associated with BMI changes among ARV recipients. In their study, first-line, second-line and thirdline of ARV and duration of treatment did not have significant effect on BMI. Factors contributed to increased BMI in HIV patients are gender, CD4 count, and DMrelated comorbidity. ${ }^{[31]}$ This explains the lack of association of treatment duration and non-diabetic subjects in our study leading to no significant difference of BMI between two groups of treatment.

We found significant difference of fasting blood glucose and fasting insulin between two groups of treatment ( $p=0.015$; $p=0.000$ ). Regarding duration of treatment, toxicity of ARV usually appears after 6-18 months duration of treatment. ARV could cause metabolic disorder, such as hyperlipidemia, lipid accumulation, insulin resistance, diabetes and osteopenia. [32] Dirajlal-Fargo et al. stated that PI and NNRTI were both associated with higher risk of DM. ${ }^{[22]}$ This result supported with study by Carr et al. Carr et al stated that PI could significantly raise blood glucose, especially in patient with and predisposed DM. This is due to metabolic effect of PI. ${ }^{[33]}$ Normal limit of fasting blood glucose is less $100 \mathrm{mg} / \mathrm{Dl}^{[34]}$ and fasting insulin is less than $13 \mu \mathrm{U} / \mathrm{ml} .{ }^{[35]}$ Subjects receiving more than 12 months of PI have had higher than normal fasting blood glucose and fasting insulin.

PI affecting blood glucose metabolism, by selectively inhibits Glucose Transporter Type 4 (GLUT4). ${ }^{[36]}$ GLUT4 is part of a family of glucose transporter proteins containing 12-transmembrane domains. It is expressed primarily in skeletal muscle and adipose tissue. It is responsible in insulin signalling. Transportation of glucose across cell membrane occurs via GLUT4's mechanism of Adenosine Triphosphate (ATP)independent facilitative diffusion. If insulin or exercise presents, GLUT4 storage vesicles will undergo exocytosis to the plasma membrane where it acts as glucose transport. Once insulin is absent, GLUT4 will enter the cell and glucose transport stops. Inhibition of GLUT4 will cause defective intracellular signalling, therefore glucose transportation is inhibited and resulted in higher blood glucose. At last, higher blood glucose will stimulate higher insulin levels in blood. ${ }^{[37]}$

There are few limitations regarding this study. First, we acknowledged the limited timeline for monitoring. Blood glucose and insulin examination are better measured regularly with longer period of monitoring as it will better represent blood glucose control of patient. Alternatively, 
HbA1c can replace blood glucose regarding this matter. Second, as we did not use $\mathrm{HbA} 1 \mathrm{C}$ as an indicator to diagnose DM type 2 in subjects, DM could be missed and may affect our result.

\section{CONCLUSION}

BMI was not associated with duration of PI therapy in our study. Fasting blood glucose and fasting insulin were significantly higher in patients receiving ARV for more than 12 months than for six to 12 months. Further investigation regarding other factors affecting blood glucose control is still needed.

\section{Acknowledgement: None}

\section{Conflict of Interest: None}

\section{Source of Funding: None}

\section{Ethical Approval: Approved}

\section{REFERENCES}

1. Anuurad E, Bremer A, Berglund L. HIV protease inhibitors and obesity: Curr Opin Endocrinol Diabetes Obes. 2010 Oct;17(5):478-85.

2. The Lancet. Maintaining the HIV response in a world shaped by COVID-19. The Lancet. 2020 Nov;396(10264):1703.

3. World Health Organization. Estimated number of people (all ages) living with HIV. 2020 [cited 2021 Apr 10]. Geneva: World Health Organization. Available from:

https://www.who.int/data/gho/data/indicat ors/indicator-details/GHO/estimatednumber-of-people-(all-ages)-living-withhiv

4. UNAIDS. Global AIDS Update 2020 [Internet]. Geneva: UNAIDS; [cited 2021 Apr 12]. Report No.: JC2991E. Available from:

https://www.who.int/data/gho/data/indicat ors/indicator-details/GHO/estimatednumber-of-people-(all-ages)-living-withhiv

5. Egger $M$, May $M$, Chêne $G$, et al. Prognosis of HIV-1-infected patients starting highly active antiretroviral therapy: a collaborative analysis of prospective studies. Lancet Lond Engl. 2002 Jul 13;360(9327):119-29.

6. Thompson-Paul AM, Wei SC, Mattson CL, et al. Obesity Among HIV-Infected Adults Receiving Medical Care in the United States: Data From the CrossSectional Medical Monitoring Project and National Health and Nutrition Examination Survey. Medicine (Baltimore). $2015 \mathrm{Jul}$;94(27):e1081.

7. Koethe JR, Jenkins CA, Lau B, et al. Rising Obesity Prevalence and Weight Gain Among Adults Starting Antiretroviral Therapy in the United States and Canada. AIDS Res Hum Retroviruses. 2016 Jan;32(1):50-8.

8. Kim DJ, Westfall AO, Chamot E, et al. Multimorbidity patterns in HIV-infected patients: the role of obesity in chronic disease clustering. J Acquir Immune Defic Syndr 1999. 2012 Dec 15;61(5):600-5.

9. Yuh B, Tate J, Butt AA, et al. Weight change after antiretroviral therapy and mortality. Clin Infect Dis Off Publ Infect Dis Soc Am. 2015 Jun 15;60(12):1852-9.

10. Fransson EI, Batty GD, Tabák AG, et al. Association between change in body composition and change in inflammatory markers: an 11-year follow-up in the Whitehall II Study. J Clin Endocrinol Metab. 2010 Dec;95(12):5370-4.

11. Sax PE, Erlandson KM, Lake JE, et al. Weight Gain Following Initiation of Antiretroviral Therapy: Risk Factors in Randomized Comparative Clinical Trials. Clin Infect Dis. 2020 Sep 15;71(6):137989.

12. Béténé A Dooko $\mathrm{C}$, De Wit $\mathrm{S}$, et al. Interleukin-6, high sensitivity C-reactive protein, and the development of type 2 diabetes among HIV-positive patients taking antiretroviral therapy. J Acquir Immune Defic Syndr 1999. 2014 Dec 15;67(5):538-46.

13. Barbaro G. Metabolic and cardiovascular complications of highly active antiretroviral therapy for HIV infection. Curr HIV Res. 2006 Jan;4(1):79-85.

14. Hruz PW. HIV protease inhibitors and insulin resistance: lessons from in-vitro, 
rodent and healthy human volunteer models. Curr Opin HIV AIDS. 2008 Nov;3(6):660-5.

15. Husain NE, Noor SK, Elmadhoun WM, et al. Diabetes, metabolic syndrome and dyslipidemia in people living with HIV in Africa: re-emerging challenges not to be forgotten. HIVAIDS Auckl NZ. 2017;9:193-202.

16. Bhagwat P, Ofotokun I, McComsey GA, et al. Changes in Waist Circumference in HIV-Infected Individuals Initiating a Raltegravir or Protease Inhibitor Regimen: Effects of Sex and Race. Open Forum Infect Dis. 2018 Nov;5(11):ofy201.

17. Chen Y-W, Hardy H, Pericone CD, Chow W. Real-World Assessment of Weight Change in People with HIV-1 After Initiating Integrase Strand Transfer Inhibitors or Protease Inhibitors. J Health Econ Outcomes Res. 2020 Jul 15;7(2):13457.

18. Bakal DR, Coelho LE, Luz PM, et al. Obesity following ART initiation is common and influenced by both traditional and HIV-/ART-specific risk factors. J Antimicrob Chemother. 2018 Aug 1;73(8):2177-85.

19. Brown TT, Li X, Cole SR, et al. Cumulative exposure to nucleoside analogue reverse transcriptase inhibitors is associated with insulin resistance markers in the Multicenter AIDS Cohort Study. AIDS. 2005 Sep 2;19(13):1375-83.

20. Obry-Roguet V, Brégigeon S, Cano CE, et al. Risk factors associated with overweight and obesity in HIV-infected people: Aging, behavioral factors but not cART in a cross-sectional study. Medicine (Baltimore). 2018 Jun;97(23):e10956.

21. Noor MA, Parker RA, O’Mara E, , et al. The effects of HIV protease inhibitors atazanavir and lopinavir/ritonavir on insulin sensitivity in HIV-seronegative healthy adults. AIDS Lond Engl. 2004 Nov 5;18(16):2137-44.

22. Dirajlal-Fargo S, Moser C, Brown TT, et al. Changes in Insulin Resistance After Initiation of Raltegravir or Protease Inhibitors With Tenofovir-Emtricitabine: AIDS Clinical Trials Group A5260s.
Open Forum Infect Dis. 2016 Sep; 3(3): ofw174.

23. World Health Organization, Regional Office for the Western Pacific, International Association for the Study of Obesity, International Obesity Task Force. The Asia-Pacific perspective: redefining obesity and its treatment. 2002.

24. Priest JL, Burton T, Blauer-Peterson C, Andrade K, Oglesby A. Clinical Characteristics and Treatment Patterns Among US Patients with HIV. Am J Manage Care. 2019;25(12):580-6.

25. Fiseha T, Belete AG, Dereje H, Dires A. Hypertension in HIV-Infected Patients Receiving Antiretroviral Therapy in Northeast Ethiopia. Int $\mathbf{J}$ Hypertens. 2019;2019.

26. Saktina PU. Karakteristik Penderita AIDS dan Infeksi Oportunistik di Rumah Sakit Umum Pusat Sanglah Denpasar Periode Juli 2013 sampai Juni 2014. E-J Med. 2017;6(3):1-6.

27. Fahme SA, Bloomfield GS, Peck R. Hypertension in HIV-infected Adults. Hypertension. 2018;72:44-55.

28. Hatleberg C, Ryom L, d'Arminio Monforte A, et al. Association between exposure to antiretroviral drugs and the incidence of hypertension in HIV-positive persons: the Data Collection on Adverse Events of Anti-HIV Drugs (D:A:D) study. HIV Med. 2018 Oct;19(9):605-18.

29. Kosasih A, Lukito AA, Soenarta AA, et al. Konsensus Penatalaksanaan Hipertensi 2019. Jakarta: Indonesia Society of Hypertension; 2019.

30. Araujo S, Bañón S, Machuca I, et al. Prevalence of insulin resistance and risk of diabetes mellitus in HIV-infected patients receiving current antiretroviral drugs. Eur J Endocrinol. 2014 Nov;171(5):545-54.

31. Tshikuka JG, Magafu MGMD, Rankgoane-Pono G, et al. Overweight and Obesity among Recipients of Antiretroviral Therapy at HIV Clinics in Gaborone, Botswana: Factors Associated with Change in Body Mass Index. AIDS Res Treat. 2020 Jan 4;2020:1-8.

32. Peraturan Menteri Kesehatan Republik Indonesia Nomor 87 Tahun 2014. 
Pedoman Pengobatan Antiretroviral. Ber Negara Repub Indones Nomor 72. 2014 Nov 11;

33. Carr A, Samaras K, Thorisdottir A, Kaufmann GR, Chisholm DJ, Cooper DA. Diagnosis, prediction, and natural course of HIV-1 protease-inhibitor-associated lipodystrophy, hyperlipidaemia, and diabetes mellitus: a cohort study. Lancet Lond Engl. 1999 Jun 19;353(9170):20939.

34. PB Perkeni. Pengelolaan dan Pencegahan Diabetes Melitus Tipe 2 di Indonesia 2015. In Perkeni; 2015.

35. Rojas J, Toledo A, Chavez M, et al. Biologic Behavior and optimal cut-off point estimation for Serum Fasting Insulin: A report from the Maracibo City
Metabolic Synrome Prevalence Study. Rev Latinoam Hipertens. 2012;7(4):80-2.

36. Murata H, Hruz PW, Mueckler M. Indinavir inhibits the glucose transporter isoform Glut4 at physiologic concentrations. AIDS Lond Engl. 2002 Apr 12;16(6):859-63.

37. Vargas E, Podder V, Sepulveda MAC. Physiology, Glucose Transporter Type 4. Treasure Island (FL): StatPearls Publishing; 2020.

How to cite this article: Nasution MAH, Pase A, Nasution MS et.al. Association between duration of protease inhibitor therapy and BMI in HIV patients. International Journal of Research and Review. 2021; 8(4): 415-421. DOI: https://doi.org/10.52403/ijrr.20210449 